Relations industrielles

Industrial Relations

\title{
Legal Aspect of Wages in Quebec
}

\section{Gérard Tremblay}

Volume 1, numéro 2, octobre 1945

URI : https://id.erudit.org/iderudit/1023902ar

DOI : https://doi.org/10.7202/1023902ar

Aller au sommaire du numéro

Éditeur(s)

Département des relations industrielles de l'Université Laval

ISSN

0034-379X (imprimé)

1703-8138 (numérique)

Découvrir la revue

Citer cet article

Tremblay, G. (1945). Legal Aspect of Wages in Quebec. Relations industrielles / Industrial Relations, 1(2), 6-6. https://doi.org/10.7202/1023902ar

Tous droits réservés (C Département des relations industrielles de l’Université Laval, 1945
Ce document est protégé par la loi sur le droit d'auteur. L'utilisation des services d'Érudit (y compris la reproduction) est assujettie à sa politique d'utilisation que vous pouvez consulter en ligne.

https://apropos.erudit.org/fr/usagers/politique-dutilisation/ 


\section{LEGAL ASPECT OF WAGES IN QUEBEC}

The legislation governing wages in the Province of Quebec comprises several laws which are complementary to one another. The following outline is intended to show how these various laws are connected to one another and to give to those who may wish to study them an accurate and comprehensive idea of our wage legislation.

1. Individual labour agreements. - Individual labour agreements are governed by the Civil Code of the Province of Quebec. Employers and wage-earners may enter into whatever individual agreements they wish, so long as they respect the minimum provisions established by decrees passed in virtue of the Minimum Wage Act or of the Collective Agreement Act.

2. Collective labour agreements. - In the Province of Quebec, collective labour agreements are negotiated freely. However, if a labour association is officially recognized as a negotiating agent by the Labour Relations Board (governed by the Labour Relations Act), the employer is bound to negotiate, in good faith, a collective labour agreement. Negotiation in good faith does not necessarily entail the signing of agreements.

If the parties are unable to reach an agreement they must solicit the intervention of a government conciliation officer and refer their dispute to a conciliation board. After the board has rendered its decision, the parties may accept it or not, but any lock-out or strike, on the part of the employer or employees respectively, is prohibited until fourteen days have elapsed since the arbitration award has been forwarded by the minister.

Every dispute between a public service (municipal or school corporation, hospital or public utility) and its employees must be submitted to arbitration. Moreover, the arbitration award rendered in such cases, whether unanimous or by majority, binds the parties for a period of one year.

3. Legal status of the collective agreement. - A collective agreement may be negotiated between one or more employers, on the one hand, and a labour organization which is not incorporated, on the other hand. Such a collective agreement is called a gentleman's agreemsnt and is valid before the Labour Relations Board. Since the passing of the Labour Relations Act, we have no precedents establishing the legal status of agreements between an employer and labour associations that are not incorporated.

The Province of Quebec has a statute that is called the Professional Syndicates' Act and which allows both employers' and employees' organizations to become incorporated. Agreements negotiated by both parties are legally valid and are enforceable before the courts just as any ordinary civil contract.
4. Juridical extension of the provisions of collective agreements. - The parties to a collective labour agreement (employers' or employees' associations) may apply to the Lieutenant-Governor in Council to have the provisions of a collective agreement (normative clauses) rendered obligatory for all employers and employees of the same trade, industry or commerce within the limits of a well-defined territory. The Lieutenant-Governor in Council may grant such a request, if it is deemed that the provisions of the collective agreement have a preponderant significance and importance. The juridical extension of collective agreements is subject to the provisions of the Collective Agreement Act, chapter 163, R.S.Q., 1941.

It is worthy of note that the parties to a collective agreement who apply to the Lieutenant-Governor in Council to have the provisions of the collective agreement juridically extended to some third parties do not necessarily have to be incorporated organizations.

Every agreement rendered obligatory in a given trade or industry within the limits of a given territorial jurisdiction constitutes a decree passed under the Collective Agreement Act. This decree is enforced by a parity committee the members of which are elected by the parties to the collective agreement. This parity committee is an autonomous body that may, as of right, by a regulation approved by the LieutenantGovernor in Council, levy upon the employers and employees subject to the decree the sums required for its administration.

5. The Minimum Wage Act. - In the Province of Quebec, the Legislative Assembly deemed it advisable that, wherever collective agreements rendered obligatory by decrees passed under the Collective Agreement Act do not exist, a Minimum Wage Commission should determine, by ordinances in accordance with the provisions of the Minimum Wage Act, minimum rates of wages and other conditions for employees.

Actually there is an ordinance (Ordinance No. 4) which applies to all wage-earners throughout the Province. It is a general ordinance which establishes minimum wages for both men and women and specifies certain working conditions for certain occupations in particular.

There are also about thirty individual ordinances governing certain industries such as the cotton textile industry, the silk textile industry, the milk industry in Montreal, etc., etc. These ordinances cease to apply as soon as a collective labour agreement is rendered obligatory by decree in the same industry. Therefore, our legislation gives priority to collective agreements.

Gerard Tremblay. 